\title{
Technology Development of Functional Dairy-Protein Products with Extracts of Medicinal Plants
}

\author{
Elena V. ULRICH \\ Ph.D. (in Technical Sciences) \\ Professor \\ Department of Agrobiotechnology \\ Kuzbass State Agricultural Academy \\ 5, Markovtsev Str., Kemerovo, 650056, Russian Federation \\ 7(904)9609496 \\ elen.ulrich@mail.ru \\ Artem E. TOLSTOY \\ $2^{\text {nd }}$-year student of the Faculty of Agrobiotechnology \\ Kuzbass State Agricultural Academy \\ 5, Markovtsev Str., Kemerovo, 650056, Russian Federation
}

\begin{abstract}
It has been established that one of the ways to improve the food product quality of $\mathrm{s}$ and expand the range of functional milk-protein products for children and adolescents is to develop formulations of milk-protein products using extracts of medicinal plants. A functional milk-protein product with a stable uniform consistency, enriched with biologically active substances of medicinal plant extracts and improved organoleptic properties for baby and adolescent nutrition, was developed in the current work. After chromatograph analysis, the content of biologically active substances in purple coneflower was determined as follow: Chicory acid (15.86\%), Caftaric acid (7.20\%), Chlorogenic acid (1.82\%), Echinacoside (3.26\%), Isobutylamides (from 0.288 to $10 \mathrm{~g}$ of extract). In the recipe number 1 - Echinacea extract was not added, in the recipe number 2 - $0.1 \mathrm{~g}$ of Echinacea extract was introduced, in the recipe number $3-0.2 \mathrm{~g}$, in the recipe number $4-0.3 \mathrm{~g}$. It was found that the optimal organoleptic functional milk protein product from frozen kefir with strawberries, Echinacea and Stevia extracts was obtained according by the recipe 3. Data analysis shows that the physicochemical parameters of functional milk protein product from frozen kefir with seasonal fruits (berries), Echinacea extracts and stevia does not contradict GOST 30625-98.
\end{abstract}

Keywords: milk-protein product; Echinacea Purpurea; Stevia; berries; organoleptic characteristics; physicochemical parameters; biologically active substances.

\section{Introduction}

Milk-protein products are products with a high content of protein and fat but low in biologically active components (Hailu et al., 2016).

Functional dairy-protein products have some lack of the following components: 
- The main polyunsaturated fatty acids: omega-3 (linolenic) and omega-6 (arachidonic and linoleic);

- Vitamins: A, C, B1, B2, B3, PP, B6, B9, E, beta-carotene;

- Macro-elements: calcium, potassium, phosphorus, magnesium, chlorine;

- Trace elements: iodine, selenium, iron, zinc, fluorine, copper, manganese, cobalt;

- Alimentary fiber;

- Natural antioxidants: bioflavonoids, anthocyanins, carotenoids, catechins, phospholipids.

Due to the variety of forms and taste, the daily ubiquitous use of milk-protein products makes it possible to attribute them to mass products. Given the growing consumption of functional dairy and protein products by the population, the creation of low-calorie and enriched with vitamins, macroand microelements products is becoming increasingly priority (Andic, Boran, 2015).

Therefore, improving the quality, nutritional and biological value, expanding the range of functional milk-protein products is becoming increasingly important.

Priority areas of industry development are:

- Reduction of sugar and fat content in foods;

- Enrichment with vitamins and minerals;

- Introduction of dietary fiber;

- Creation and implementation of innovative technologies of functional milk-protein products with high nutritional and biological value for children and adolescents.

When developing functional milk-protein products for children and adolescents, in addition to unique biochemical properties, non-traditional types of raw materials must fulfill certain functional and technological properties in order to create products with original organoleptic properties (taste, aroma, structure), to ensure their quality during storage (Hailu et al., 2016).

One of the ways to increase the functionality of milk protein products for children and adolescents is to create formulations with additives of plant materials. This is due to availability, renewable resources, environmental friendliness and low cost. Such additives may be administered in the form of powders and extracts. At the same time, preference is given to local plant raw materials and products of its processing (Andic, Boran, 2015). 
As herbal additives, flowers of nettle, raspberry, blackcurrant, and linden are used. The resulting products have a pleasant taste and aroma, improve their structure and texture. In addition, the use of such additives can increase the content of biologically active substances and increase their therapeutic and prophylactic properties. With the introduction of herbal medicinal raw materials (powder of leaves of frankincense, seaweed, beets, St.-John's-wort), the amino acid composition of functional milk-protein products for children and adolescents increases, as well as the content of minerals (calcium and iron) raises (Chernopolskaya, 2019).

A promising direction is the replacement of fatty raw materials with additives that have good waterholding, fat-binding and fat-emulsifying ability (Mikryukova, 2012, Suthar et al., 2017). Powders from pressed red and black currants, pumpkins, tangerines and their zest are used as these additives. Such powders are rich in fiber (pectin, cellulose, hemicellulose), water-soluble proteins.

Also it known a technological scheme for the production of functional milk-protein products for children and adolescents using cedar flour and dehydrated berries (Suthar et al., 2017). Due to the increased nutritional value and high content of fat, nitrogenous substances and vitamins of groups $\mathrm{E}$ and B (cedar flour), finished products acquire dietary properties, as they contain natural plant components. Functional milk-protein products with such additives are characterized by high organoleptic characteristics: bright color, natural taste and smell, characteristic of the used fruit and berry raw materials, which is important for the nutrition of children and adolescents. Shelf life also increases, the cost of the finished product decreases (Suthar et al., 2017, Ricci-Cabello, et al., 2012). Increasing biological value of functional milk protein products for children and adolescents is achieved through the use of pastes and powders prepared from cranberry meal (Mikryukova, 2012). Thanks to the added substances, the products acquire a pleasant pinkish color, as well as the taste of berries, which significantly improves their consumer properties. The introduction of additives from cranberry processing products increases the content of proteins, minerals and vitamins, and calorie content decreases.

Another promising way is the development of technologies for obtaining new types of functional milk-protein products for children and adolescents using grape processing products. The use of grape processing products allows creating a new range of functional milk-protein products by using natural dyes, antioxidants with high nutritional and biological value, as well as with original organoleptic properties (Chernopolskaya, 2019).

Improving the quality of food products and expanding the range of functional milk-protein products for children and adolescents is the development of milk-protein products using plant materials, including pumpkin (Chernopolskaya, 2019). The main advantages of pumpkin are a high content of 
$\beta$-carotene, pectin and fiber, low calorie content. The fruits of pumpkin are indispensable in dietary and therapeutic nutrition. The use of vegetable pumpkin puree and herbal additives in the production of functional milk-protein products for children and adolescents allows not only to improve the taste and nutritional properties and eliminate synthetic dyes, flavorings from the recipe, but also to increase the biological value of the finished product. In these products based on pumpkin puree, in addition to $\beta$-carotene, pectin and fiber, there are vitamins and trace elements that allow them to be positioned as products of high biological and nutritional value (Chernopolskaya, 2019).

One of the urgent problems in connection with the spread of type-2 diabetes among the younger generation is the decrease in sugar content in functional milk-protein products for children and adolescents (Mikryukova, 2012). Of interest is the replacement of sugar with low-calorie additives, for example, a powdered extract of stevia. This allows preserving not only sweet taste, but also almost all the nutrients that stevia is rich in. In addition, when using powdered extracts of stevia, the caloric content of functional milk-protein products for children and adolescents is reduced, thereby reducing the risk of adolescent obesity. Introduction to the extract of Echinacea extract increases the degree of satisfaction of the daily needs of the body in biologically active substances (Suthar et al., 2017).

Introduction of non-traditional and local plant materials for the production of new types of functional dairy protein products for children and adolescents of mass production, enriched with proteins, trace elements, mineral salts, dietary fiber, can not only increase the nutritional and biological value of functional dairy protein products, but also reduce sugar consumption fat. Therefore, further work on the use of types of plant materials, as well as functional food additives should be related to priority areas in the production of functional milk-protein products for children and adolescents (Andic, Boran, 2015).

During the study, components were selected to obtain a functional milk-protein product from frozen kefir with extracts of seasonal fruits (berries), Echinacea and Stevia.

\section{Methods}

Components for obtaining functional milk-protein product:

- Echinacea Purpurea GOST 937916;

- Kefir with a fat content of $2.5 \%$ GOST 31454 ;

- Stevia GOST R 53904;

- $\quad$ Fruits GOST R 57976; 
- Strawberries GOST R 53884.

In the course of the work, 4 samples of a milk-protein product with a different content of Echinacea Purpurea extract with a fixed content of fruits (berries) and Stevia were made.

- Qualitative and quantitative determination of biologically active substances in the extract of Echinacea Purpurea was carried out by chromatographic methods.

When performing work, there were used generally accepted standard research methods such as:

- Organoleptic and physico-chemical parameters of the milk-protein product according to GOST 30625-98.

Echinacea Purpurea is an herbaceous perennial plant that contains a large amount of nutrients that can be beneficial to humans.

The plant contains essential oils, vitamins, polysaccharides, tannins, resins, organic acids, glycosides, alkaloids. Echinacea contains flavonoids, enzymes, inulin, phosphates, fiber, saponins and phytosterols. The plant contains phenolic acids and polyenes - substances that destroy various types of fungi. The chemical composition of Purple Echinacea: calcium; potassium; selenium; iron; silicon; cobalt; zinc; manganese; carotene; vitamins E, C, A.

In traditional medicine, its flower is used to treat: pneumonia, bronchitis; diseases of the bladder and liver; poliomyelitis; smallpox diseases of the female reproductive system; blood poisoning; diabetes mellitus; oncological diseases; exposure to heavy metals and fungicides.

The main advantage of Echinacea is that substances based on it have a beneficial effect on the immune system, strengthening the body's defenses (Hailu et al., 2016).

A therapeutic dose (from the Latin "therapeutica" - therapeutic) is a dose of a pharmaceutical agent that causes the desired therapeutic effect in a patient.

For therapeutic purposes, it is recommended to take dry extract of Echinacea (containing 3.5\% echinacosides): 100-250 mg three times a day (Hailu et al., 2016).

Daily dose (doses per day) - the number of preparation prescribed for use during the day.

As part of the daily portion of biologically active substances (biologically active additives), the content of pharmacologically active compounds of the medicinal plant should be no more than 50$60 \%$ of a single therapeutic dose when using the plant as a medicine. Moreover, the lower limit of the content of these compounds in food additives should be at least $10 \%$ of a single therapeutic dose. Thus, on the one hand, Echinacea extract ensured the presence of the most important 
compounds in food supplements, on the other hand, did not imply the presence of its medicinal properties, and thirdly, it provided protection for the criterion for the content of specific pharmacologically active components. This aspect is considered the most important reference point when deciding on the dose of a certain biologically active substance in a biologically active additive (Hailu et al., 2016).

Description of TLC methods (thin layer chromatography): before starting work, it is necessary to prepare solutions of standard samples (SS) and Echinacea Purpurea extract.

To prepare SS solution in amount of $10 \mathrm{mg}$ (exact weight) of a particular biologically active substance, previously dried at a temperature of $100-105^{\circ} \mathrm{C}$ for 3 hours, was placed in a $100 \mathrm{ml}$ volumetric flask, where $30 \mathrm{ml}$ of ethyl alcohol was added and stirred. Then bring the volume of the solution with alcohol to the mark and mix again.

Echinacea Purpurea extract must be poured with a mixture of water-ethanol with an ethanol concentration of $70 \%$.

The test solution (extract of Echinacea Purpurea) and a solution of biologically active substances in accordance with Table 3 are applied to the start line of the analytical chromatographic plate with a layer of silica gel on an aluminum substrate. The tablet with the applied samples is dried at the temperature and time indicated in Table 3, placed in a chamber, pre-saturated for 30 minutes with a mixture of solvents (Table 3) and chromatographed. When the solvent front passes about $80-90 \%$ of the plate length from the start line, it is removed from the chamber, dried to remove any traces of solvents, heated in an oven at $100-105{ }^{\circ} \mathrm{C}$ for 3-5 minutes and treated with diphenylboronic acid amino-ethyl ester by a $1 \%$-solution in $96 \%$-alcohol and viewed in UV-light at the wavelength indicated in Table 1.

On the chromatogram of the test solution, an adsorption zone with intense fluorescence at the level of the zone in the chromatogram of BAD SS solutions should be detected (Table 1).

Table 1. TLC Methodology Parameters

\begin{tabular}{ccccccccc} 
№ & $\begin{array}{c}\text { Name of the } \\
\text { medicinal } \\
\text { plant }\end{array}$ & $\begin{array}{c}\text { Amount } \\
\text { of test } \\
\text { solution, } \\
\boldsymbol{\mu l}\end{array}$ & $\begin{array}{c}\text { Amount } \\
\text { of CO, } \boldsymbol{\mu l}\end{array}$ & $\begin{array}{c}\text { Drying } \\
\text { time, } \\
\text { min }\end{array}$ & $\begin{array}{c}\text { Drying } \\
\text { temperatur, } \\
\mathbf{0} \mathbf{C}\end{array}$ & $\begin{array}{c}\text { Solvent } \\
\text { mixture }\end{array}$ & $\begin{array}{c}\text { Wave } \\
\text { length, } \\
\text { nmm }\end{array}$ & $\begin{array}{c}\text { Fluorescence } \\
\text { color }\end{array}$ \\
\hline 1 & $\begin{array}{c}\text { Echinacea } \\
\text { Purpurea } \\
\text { (Echinacea) }\end{array}$ & 20 & 20 & 20 & 30 & $\begin{array}{c}\text { N-butanol- } \\
\text { acetic acid- } \\
\text { water }(4: 1: 2)\end{array}$ & 265 & Violet \\
\end{tabular}

Chromatogram fluorescence portions are indicated by a color corresponding to a specific biologically active substance in medicinal plants. 
IV International Scientific and Practical Conference "Modern S\&T Equipments and Problems in Agriculture"

It is allowed to detect other adsorption zones (in the case of the determination of several biologically active substances).

According to literature data, it is known that biologically active substances are found in all parts of purple coneflower, but the distribution of biologically active substances in the roots, leaves and flowers of purple coneflower is not the same (Hailu et al., 2016).

For analysis, an extract was taken from Echinacea Purpurea flowers obtained by the method of lowtemperature vacuum water-ethanol extraction followed by low-temperature vacuum drying at "Kemerovo Pharmaceutical Factory" OJSC. Determination of biologically active substances of Echinacea Purpurea was carried out on the basis of the Kemerovo State Medical University.

Echinacea has antiviral, antibacterial and antimicrobial effects.

The Echinacea usefulness is considered one of the most popular medicinal plants in the world. Many healers are sure that in its healing properties it is superior to ginseng and can cure many diseases.

The ratio of the total amount of biologically active substances between the various parts of Echinacea Purpurea is shown in Figure 1.

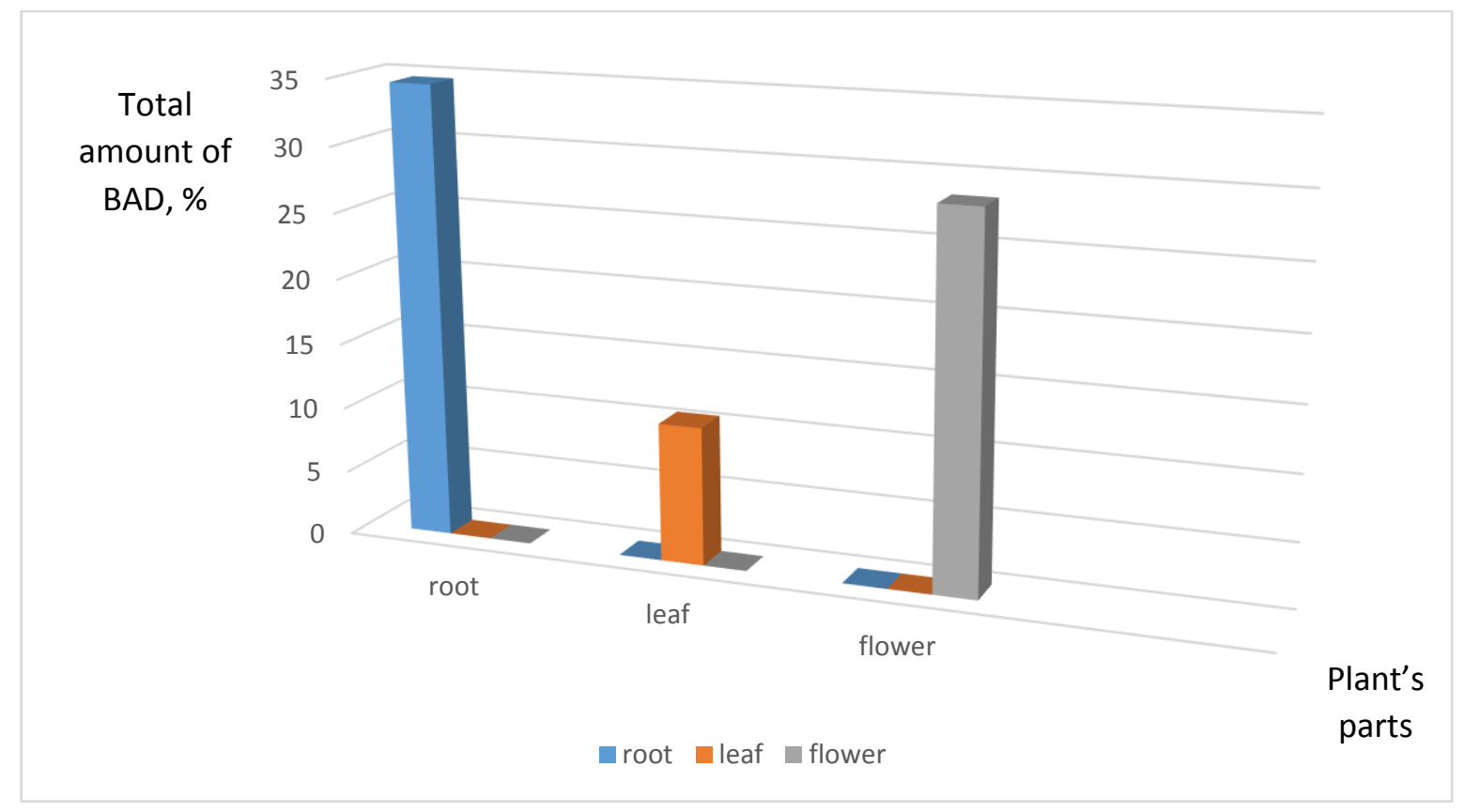

Figure 1. The ratio of the BAD total amount between the various parts of Echinacea Purpurea

According to Figure 1, it follows that all parts of the plant contain biologically active substances, but roots of Echinacea Purpurea deposit the largest nart of the medicinal substances (Ricci-Cabello et al., 2012). 
The conditions for the analysis are presented in Table 2.

Table 2. Conditions for analysis of Echinacea Purpurea extract

\begin{tabular}{|c|c|}
\hline Sample weight & $10 \mathrm{~g}$ \\
\hline $\begin{array}{l}\text { Results of external examination and } \\
\text { sample mass }\end{array}$ & $\begin{array}{l}\text { Loose yellow-brown powder, specific odor. Packed in a plastic bag with } \\
\text { a zipper. }\end{array}$ \\
\hline Conditions of analysis process & $\begin{array}{ccc}\text { Temperature }- & \text { Humidity - } & \text { Barometric pressure - } \\
23.3^{\circ} \mathrm{C} & 42.1 \mathrm{rel} \% & 99.1 \mathrm{kPa} \\
\end{array}$ \\
\hline Measuring tools & $\begin{array}{l}\text { TLC-conditions with densitometry of TLC plates Sorbfil PTSX-AF-A. } \\
\text { Densitometer (IMID Ltd., Russia) with Soni photofixation system. } \\
\text { UV-FT on the FSM -1202 device (Infraspek). }\end{array}$ \\
\hline Analysis conditions & $\begin{array}{l}1 \mathrm{~cm}^{3} \text { of a standard ferulic acid solution with a concentration of } 0.1 \\
\mathrm{mg} / \mathrm{cm}^{3}(100 \mu \mathrm{g}) \text { was added to } 1 \mathrm{~cm}^{3} \text { of extract. Column with sorbent } \mathrm{C} 18 \\
\text { "Kromasil C-18" }(250 \times 4.6 \mathrm{~mm}) \text {. Mobile phase: acetonitrile }-0.05 \mathrm{M} \\
\mathrm{NaH} 2 \mathrm{PO} 4, \mathrm{pH} 2.6(15: 85) \text {; flow rate is } \\
1.2 \mathrm{~cm}^{3} / \mathrm{min} \text {; detection is at } \lambda=330 \mathrm{~nm} \text {; sample volume }-20 \mu \mathrm{l} .\end{array}$ \\
\hline
\end{tabular}

Analysis of tabular data showed that the studies were carried out on an HPLC chromatograph with diode-matrix detection.

Description of HPLC methods (high performance liquid chromatography). Before starting work, it is necessary to prepare solutions of the extract of SS and Echinacea Purpurea.

To prepare solutions of SS in amount of $10 \mathrm{mg}$ (accurate weighing) of a particular biologically active substance, previously dried at a temperature of $100-105^{\circ} \mathrm{C}$ for 3 hours, was placed in a volumetric flask with a capacity of $25 \mathrm{ml} ; 30 \mathrm{ml}$ of a mixture of ethyl and methyl alcohol are added. Then bring the volume of the solution with alcohol to the mark and mix.

Echinacea Purpurea extract was placed in a $200 \mathrm{~cm}^{3}$ flask; $100 \mathrm{~cm}^{3}$ of ethanol-water mixture was added, and extraction was carried out by heating in a boiling water bath under reflux for 10-15 min. Cool the extract to room temperature and filter through a paper filter. The ethanol concentration for extraction is $70 \%$.

Before starting work, a new chromatographic column is put into reverse phase operation. For this, the column is washed with $40 \mathrm{~cm}^{3}$ of isopropanol, then with $80 \mathrm{~cm}^{3}$ of deionized water, after which the column is balanced with the mobile phase to a stable zero line (Chubarova et al., 2013).

On the start line of the analytical chromatographic column with silica gel chemically bonded to Nucleosil C-18 octadecylsilane $(250 \times 4.6 \mathrm{~mm})$, the test solution (extract of the medicinal plant) and the solution of the biologically active substance SS are added in accordance with Table 2. The analysis is carried out using liquid chromatograph with a UV spectrophotometric detector at the wave length indicated in Table 3. The chromatographic column is pre-saturated for 30 minutes with a mixture of solvents (Table 3). 
Table 3. HPLC Method Parameters

\begin{tabular}{ccccccc} 
№ & $\begin{array}{c}\text { Name of the } \\
\text { medicinal plant }\end{array}$ & $\begin{array}{c}\text { Number of } \\
\text { test solution, } \\
\boldsymbol{\mu l}\end{array}$ & $\begin{array}{c}\text { Amount of } \\
\text { SS, } \boldsymbol{\mu l}\end{array}$ & Solvent mixture & $\begin{array}{c}\text { Wave length of } \\
\text { the UV } \\
\text { detector, } \mathbf{n m}\end{array}$ & $\begin{array}{c}\text { Color of } \\
\text { adsorption } \\
\text { zone }\end{array}$ \\
\hline 8 & $\begin{array}{c}\text { Echinacea } \\
\text { Purpurea } \\
\text { (Echinacea) }\end{array}$ & 20 & 20 & $\begin{array}{c}\text { N-butanol-acetic acid- } \\
\text { water }(4: 1: 2)\end{array}$ & 265 & Violet \\
\end{tabular}

The chromatographic column has a separation into zones during the movement of SS and test solutions of Echinacea Purpurea with a mobile phase. An ultraviolet detector constantly records signals in the ultraviolet and visible regions of the spectrum, thereby ensuring the recording of UV spectra (chromatograms) in scanning mode. Further chromatograms are identified and decoded.

SS and test solution are chromatographed at least three times.

The quantitative content of biologically active substances in Echinacea Purpurea is determined by the formula:

$$
\mathrm{X}=\frac{K \times C \times S^{1} \times V \times 100 \%}{S_{2} \times M}
$$

where $\mathrm{C}$ - concentration of SS in the analyzed sample, $\mathrm{mg} / \mathrm{ml}$;

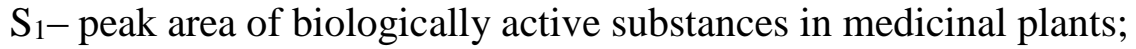

$\mathrm{S}_{2}-$ peak area of SS;

$\mathrm{V}$ - total volume of the extract of the medicinal plant, ml;

$\mathrm{M}$ - mass of a medicinal plant sample, mg;

$\mathrm{K}$ - coefficient taking into account the difference in UV absorption of SS and determined biologically active substances.

\section{Results}

The data obtained as a result of chromatographic analysis are presented in Table 4.

Table 4. BAD of Echinacea Purpurea

\begin{tabular}{ccccc}
$\begin{array}{c}\text { Group of } \\
\text { indicators }\end{array}$ & $\begin{array}{c}\text { Measured } \\
\text { indicator }\end{array}$ & Sample standard & $\begin{array}{c}\text { Test } \\
\text { result }\end{array}$ & Research assessment references \\
\hline \multirow{2}{*}{ BAD } & Chicory acid & Ferulic acid & $\begin{array}{c}15.86 \% \\
(1.586 \mathrm{~g})\end{array}$ & $\begin{array}{c}\text { P 4.1.1672-03 } \\
\text { HPLC }\end{array}$ \\
\cline { 2 - 5 } & & & $7.20 \%$ & P 4.1.1672-03 \\
& Kaftaric acid & Ferulic acid & $(0.72 \mathrm{~g})$ & HPLC
\end{tabular}


IV International Scientific and Practical Conference "Modern S\&T Equipments and Problems in Agriculture"

Chlorogenic acid

Ferulic acid

$1.82 \%$

$(0.182 \mathrm{~g})$

P $4.1 .1672-03$

HPLC

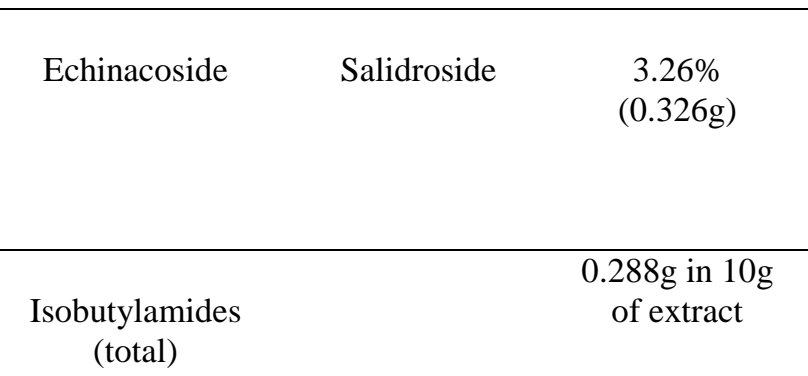

C.M. Gilroy, J.F. Steiner, T. Byers, H. Shapiro, W. Georgian, Echinacea andtruth in labeling, Arch. Int. Med. V.163 2003. P. 699-704.

TLC

\begin{tabular}{ccc}
\hline $\begin{array}{c}\text { Isobutylamides } \\
\text { (total) }\end{array}$ & $\begin{array}{c}0.288 \mathrm{~g} \text { in } 10 \mathrm{~g} \\
\text { of extract }\end{array}$ & $\begin{array}{c}\text { R. Bauer, P. Remiger, H. Wagner, } \\
\text { Alkamides from the roots of } \\
\text { Echinaceapurpurea, }\end{array}$ \\
& $\begin{array}{c}\text { Phytochemistry.V. 27. 1988. P. } \\
\text { 2339-2342. }\end{array}$ \\
HPLC + TLC + UV - FT
\end{tabular}

Analysis of tabular data allows concluding that the presence and quantitative composition of biologically active substances is characteristic of Echinacea Purpurea. After analysis by chromatography, we determined the content of biologically active substances in Echinacea Purpurea: Chicory acid (15.86\%), Caftaric acid (7.20\%), Chlorogenic acid (1.82\%), Echinacoside (3.26\%), Isobutylamides ( $0.288 \mathrm{~g}$ per $10 \mathrm{~g}$ of extract).

The diagram in Figure 2 shows the relationship between the individual biologically active substances in the Echinacea Purpurea extract.

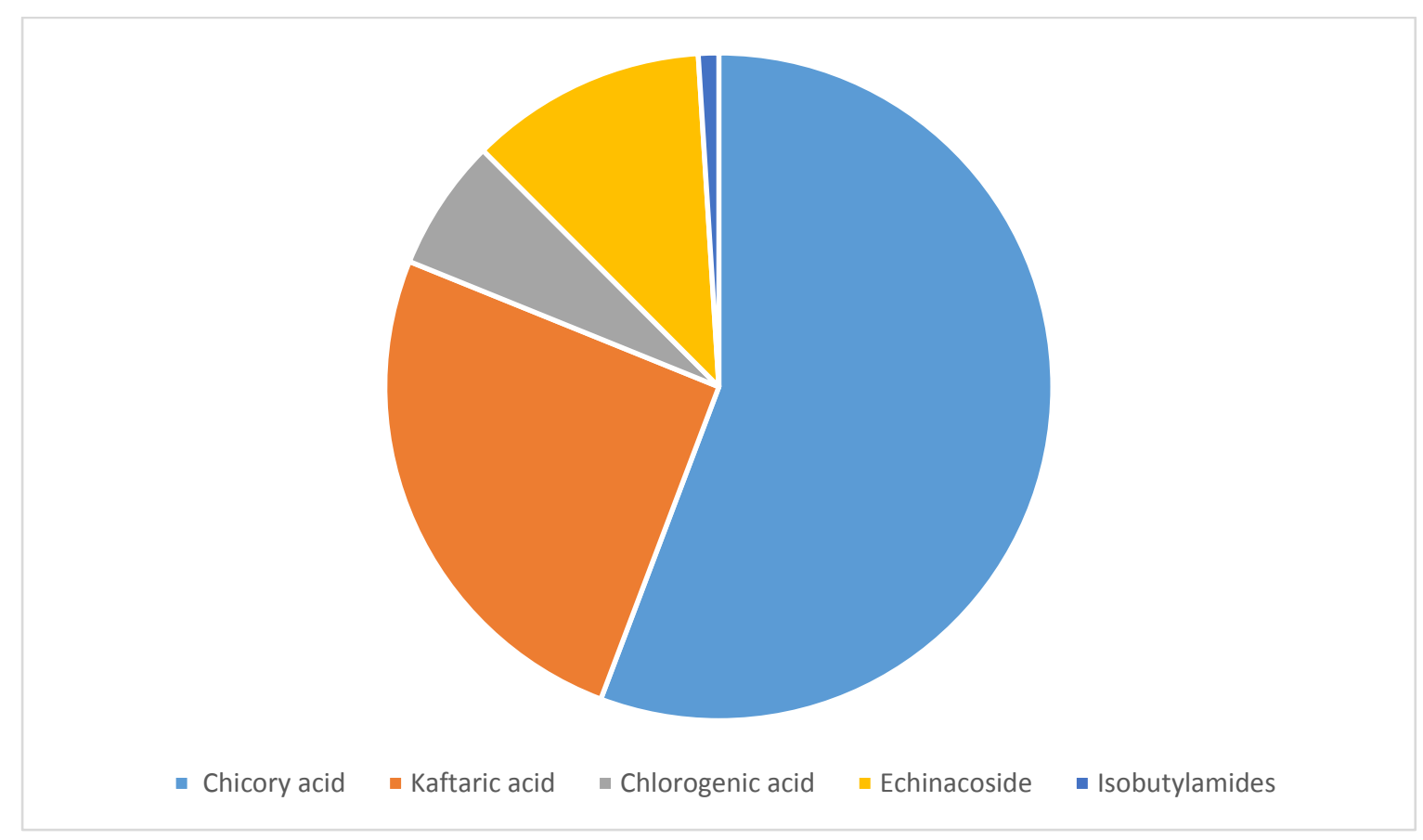

Figure 2. Diagram of the BAD distribution by component

Analysis of Figure 2 allows drawing conclusions about the predominant content of chicory acid in the total composition of biologically active substances of Echinacea Purpurea. 
The diagram showed a higher content of Chicory acid than other components of biologically active substances. Chicory acid has anti-inflammatory and antimicrobial effects. Stimulates chemotaxis, promotes the release of cytokines, increases the phagocytic activity of macrophages. With course therapy, an increase in immunity and resistance to adverse factors is noted. Echinacea Purpurea preparations with a high content of Chicory acid have high activity against streptococcus, herpes viruses, staphylococcus, E. coli. In addition, the plant has the following properties: anticarcinogenic; antiviral; hemostatic; immunomodulatory; antitumor; antispasmodic; hepatoprotective; antiallergic; healing antifungal; antioxidant and anti-aging one. Echinacea Purpurea extracts are often used to treat burns. In addition, they are able to accelerate the healing of purulent wounds, skin rashes, eczema, relieve pain, protect the body from viruses and bacteria. The plant has a depressing effect on streptococci and E. coli. Echinacea Purpurea is one of the most powerful plant immunostimulants that helps to cope with various diseases faster. The main advantage of Echinacea is that drugs based on it have a beneficial effect on the immune system, strengthening the body's defenses. This is due to the fact that the composition of the herb includes a huge amount of chicory acid, as well as Kaftaric, Chlorogenic acids, Echinacosides, trace elements, essential oils. In addition, Echinacea contains polysaccharides, tannins, glucose, etc. (Jackson et al., 2012).

\section{Discussion}

Research was conducted on the development of a formulation and technology for the production of a functional milk-protein product from frozen kefir with seasonal fruits (berries), Echinacea and Stevia extracts.

During the study, four samples of the milk protein product were prepared. No Echinacea extract was added to the formula-1; $0.1 \mathrm{~g}$ of Echinacea extract was added to the formula-2; $0.2 \mathrm{~g}$ to the formula-3, and $0.3 \mathrm{~g}$ to the formula-4. Examples of formulations are shown below in Table 5 .

Table 5. Formulas of a functional milk protein product made from frozen kefir with seasonal fruits (berries) with Echinacea and Stevia extracts

\begin{tabular}{cccccc}
\multirow{2}{*}{ No } & Name of component & \multicolumn{4}{c}{ Consumption of raw materials, $\mathbf{g}$} \\
\cline { 3 - 6 } & & Formula-1, $\mathbf{g}$ & Formula-2, $\mathbf{g}$ & Formula-3, $\mathbf{g}$ & Formula-4, $\mathbf{g}$ \\
\hline 1 & Frozen Kefir & 100 & 100 & 100 & 100 \\
\hline 2 & Strawberries & 5 & 5 & 5 & 5 \\
\hline 3 & Stevia extract & 0.7 & 0.7 & 0.7 & 0.7 \\
\hline 4 & Echinacea Purpurea & - & 0.1 & 0.2 & 0.3
\end{tabular}

Echinacea Purpurea is present in three recipes in different proportions. 
The technology for preparing a functional milk-protein product from frozen kefir with extracts of seasonal fruits (berries), Echinacea and Stevia was divided into several stages:

The first stage - kefir with a fat content of $2.5 \%$ was frozen at $\mathrm{T}=-190{ }^{\circ} \mathrm{C}$ for 1 hour. The content of valuable components of the fermented milk product is preserved in frozen kefir, so the shelf life of the milk-protein product obtained from it is increased.

The second stage - kefir was thawed at room temperature for 1 hour, the excess liquid was separated through a sieve.

The third stage - thoroughly washed and dried strawberries were prepared.

The fourth stage - thawed kefir with strawberries were placed in a blender, and dry extracts of Echinacea and Stevia were poured according to the developed recipes. The components were ground and mixed to a uniform consistency for 2 minutes. Then the milk-protein product was poured into any plastic or glassware.

The fifth stage - an organoleptic evaluation of the finished product was carried out.

The sixth stage - the physicochemical parameters of the functional milk-protein product were determined.

After obtaining a functional milk-protein product from frozen kefir with seasonal fruits (berries), Echinacea and Stevia extracts, its organoleptic properties were determined for all four formulations, which are listed below in Table 6.

Table 6. Organoleptic indicators of functional milk-protein product

\begin{tabular}{|c|c|c|c|c|c|}
\hline Name & Taste & Odor & Color & Consistency & $\begin{array}{c}\text { BAD of } \\
\text { Echinacea (total), }\end{array}$ \\
\hline
\end{tabular}

\begin{tabular}{|c|c|c|c|c|c|}
\hline Formula-1 & $\begin{array}{l}\text { Weak sour milk } \\
\text { taste with a } \\
\text { strawberry flavor }\end{array}$ & $\begin{array}{l}\text { Mild strawberry } \\
\text { flavor }\end{array}$ & Pink & $\begin{array}{l}\text { Homogeneous, } \\
\text { tender, moderately } \\
\text { viscous, soft } \\
\text { graininess is } \\
\text { allowed }\end{array}$ & - \\
\hline Formula-2 & $\begin{array}{l}\text { Weak sour milk } \\
\text { taste with a } \\
\text { strawberry flavor }\end{array}$ & $\begin{array}{l}\text { Mild strawberry } \\
\text { flavor }\end{array}$ & Pink & $\begin{array}{l}\text { Homogeneous, } \\
\text { tender, moderately } \\
\text { viscous, soft } \\
\text { graininess is } \\
\text { allowed }\end{array}$ & 0.032 \\
\hline
\end{tabular}


IV International Scientific and Practical Conference "Modern S\&T Equipments and Problems in Agriculture"

\begin{tabular}{|c|c|c|c|c|c|}
\hline Formula-3 & $\begin{array}{l}\text { Weak sour milk } \\
\text { taste with a } \\
\text { strawberry flavor }\end{array}$ & $\begin{array}{l}\text { Mild strawberry } \\
\text { flavor }\end{array}$ & Pinkish & $\begin{array}{l}\text { Homogeneous, } \\
\text { tender, moderately } \\
\text { viscous, soft } \\
\text { graininess is } \\
\text { allowed }\end{array}$ & 0.068 \\
\hline Formula-4 & $\begin{array}{c}\text { Slightly sour milk } \\
\text { taste, with a light } \\
\text { grassy flavor }\end{array}$ & Mild grassy flavor & Grayish & $\begin{array}{l}\text { Homogeneous, } \\
\text { tender, moderately } \\
\text { viscous, soft } \\
\text { graininess is } \\
\text { allowed }\end{array}$ & 0.094 \\
\hline
\end{tabular}

The analysis of tabular data shows the similarity and difference of the main indicators of various compositions of the milk-protein product.

The optimal organoleptic characteristics are functional milk-protein products from frozen kefir with strawberries, extracts of Echinacea and Stevia, obtained according to formula-3.

It was found that the appearance and consistency of a functional milk-protein product are optimal for the usual taste of a child or adolescent (McGregor, Poppitt, 2013).

Physico-chemical indicators of functional milk-protein product according to the formula-3, which showed the best organoleptic properties, are presented in Table 7.

Table 7. Physico-chemical parameters of milk-protein product according to the formula-3

\begin{tabular}{cccc} 
No & Name of indicator & Value of indicator, \% & $\begin{array}{c}\text { Method of } \\
\text { determination }\end{array}$ \\
\hline 1 & Mass fraction of fat & 2.5 & GOST 30648.1. \\
\hline 2 & Mass fraction of protein & 3.0 & GOST 30648.2. \\
\hline 3 & Carbohydrate content & 14.4 & GOST 30648.5. \\
\hline 4 & Mass fraction of dry skim milk & 8.52 & GOST 30648.3. \\
\hline 5 & Mass fraction of vitamin A & 2.2 & GOST 30627.1 \\
\hline 6 & Mass fraction of vitamin C & 1.05 & GOST 30627.2
\end{tabular}

Analysis of the tabular data shows that the physicochemical parameters of a functional milk-protein product from frozen kefir with extracts of seasonal fruits (berries), Echinacea and Stevia do not contradict the data of GOST 30625-98.

\section{Conclusion}

As a result of theoretical and experimental studies, the main goal of the work was achieved: the technology of a functional milk-protein product with an extract of Echinacea, fruit and Stevia was developed and tested.

During the study, all tasks were solved: 
IV International Scientific and Practical Conference "Modern S\&T Equipments and Problems in Agriculture"

1. The role of herbal supplements and extracts of medicinal plants in the technology of functional milk-protein products for children and adolescents is justified.

2. The formulation of a functional milk-protein product with Echinacea extract, fruits and Stevia was developed.

3. The organoleptic characteristics of a functional milk-protein product with an extract of with Echinacea extract, fruits and Stevia were determined.

4. The physicochemical properties of a functional milk-protein product with an extract of Echinacea, fruit, and Stevia are determined.

As a result of the work done, the main practical goal of the planned results is proved:

A functional milk-protein product with a stable, uniform consistency, enriched with biologically active substances of extracts of medicinal plants and improved organoleptic properties for children and adolescent nutrition, has been developed.

\section{References}

Andic, S., Boran, G. (2015). Milk Proteins: Functionality and Use in Food Industry. Functional Polymers in Food Science, 3, 113-116. DOI: 10.1002/9781119108580.ch8

Anema, S.G., Li, Y. (2003). Association of denatured whey proteins with casein micelles in heated reconstituted skim milk and its effect on casein micelle size. Journal of Dairy Research, 70, 73-83. DOI: 10.1017/S0022029902005903

Chernopolskaya, N.L. (2019). Research and development of technologies for specialized milkbased fermented products. Polzunovsky Bulletin, 2, 55-58.

Chubarova, A.I., Weinstein, N. P., Volodin, N. N. (2013). Protein and amino acids in the nutrition of premature babies. Questions of practical Pediatrics, 8(1), 40-49.

Hailu, Y, Hansen, E, Seifu, E, Eshetu, M, Ipsen, R, Kappeler, S. (2016). Functional and technological properties of camel milk proteins: a review. Journal of Dairy Research, 83(4), 422-429. DOI: 10.1017/S0022029916000686

Jackson, K.G., Poppitt, S.D., Minihane, A.M. (2012). Postprandial lipemia and cardiovascular disease risk: Interrelationships between dietary, physiological and genetic determinants. Atherosclerosis, 220(1), 22-33. DOI: 10.1016/j.atherosclerosis.2011.08.012

McGregor, R.A., Poppitt, S.D. (2013). Milk protein for improved metabolic health: a review of the evidence. Nutrition \& Metabolism, 10, 46. DOI: 10.1186/1743-7075-10-46 
IV International Scientific and Practical Conference "Modern S\&T Equipments and Problems in Agriculture"

Mikryukova, N.V. (2012). The main aspects of functional food obtaining. Young Scientist, 12(47), 90-92.

Ricci-Cabello, I., Herrera, M.O., Artacho, R. (2012). Possible role of milk-derived bioactive peptides in the treatment and prevention of metabolic syndrome. Nutrition Reviews, 70(4), 241-255. DOI: 10.1111/j.1753-4887.2011.00448.x

Suthar, J., Jana, A., Balakrishnan, S. (2017) High Protein Milk Ingredients - A Tool for ValueAddition to Dairy and Food Products. Journal of Dairy, Veterinary \& Animal Research, $6(1), 00171$. 